\title{
Glacier changes from 1975 to 2016 in the Aksu River Basin, Central Tianshan Mountains
}

\author{
ZHANG Qifei ${ }^{1,2},{ }^{*}$ CHEN Yaning ${ }^{1}$, LI Zhi ${ }^{1}$, LI Yupeng ${ }^{1,2}$, XIANG Yanyun $^{1}$, BIAN Wei ${ }^{1,2}$ \\ 1. State Key Laboratory of Desert and Oasis Ecology, Xinjiang Institute of Ecology and Geography, CAS, \\ Urumqi 830011, China; \\ 2. University of Chinese Academy of Sciences, Beijing 100049, China
}

\begin{abstract}
In this study, we analyzed glacier changes in the Aksu River Basin during the period 1975-2016, based on Landsat MSS/TM/ETM+/OLI imagery analysis and the Chinese Glacier Inventory (CGI). The results showed that the total number, area, and volume of the studied glaciers in the Aksu River Basin decreased by 202 (7.65\%), $965.7 \mathrm{~km}^{2}(25.88 \%)$, and $74.85-78.52 \mathrm{~km}^{3}(23.72 \%-24.3 \%)$, respectively. The rate of glacier retreat in the basin was slower in the north, northwest and west, but reached the highest in the east (measuring $0.86 \% \mathrm{yr}^{-1}$ ). Furthermore, there were significant regional differences in the distribution and change of glaciers, the Kumalak River Basin had the largest glacier number and area, about $63.15 \%$ and $76.47 \%$ of the studied basin, and the rate of glacier retreat in the Kumalak River Basin was $0.65 \% \mathrm{yr}^{-1}$, it was higher than the Toxkan River Basin which reached $0.57 \% \mathrm{yr}^{-1}$. We found the shrinkage rate of glacier for different periods in the past 41 years, during 1975-1990 the glaciers showed the greatest retreat, while the rate of glacier area retreat slowed down significantly from 1990 to 2000. In recent 16 years since 2000, the rate of glacier retreat in the Toxkan River Basin was higher compared with 1990-2000. The RGI50-13.04920 glacier of Kumalak River Basin had been in a state of retreat since 1990. Over the past 41 years, the temperature and precipitation in the Aksu River Basin increased obviously, and the warming temperatures were clearly the main reason for glacier retreat in the region, while the increased precipitation in the mountain area may have a direct relation with the retreating rate of glaciers.
\end{abstract}

Keywords: glacier change; glacier retreat; remote sensing; Aksu River Basin

\section{Introduction}

Mountain glaciers are an important component of the cryosphere, not only are they considered early warning devices and natural key indicators of climate change (Oerlemans, 2005;

Received: 2018-03-22 Accepted: 2018-09-29

Foundation: National Natural Science Foundation of China, No.41630859, No.41471030

Author: Zhang Qifei, PhD, specialized in glacier change and water resources. E-mail: zhangqifei15@mails.ucas.ac.cn

"Corresponding author: Chen Yaning, Professor, specialized in hydrology and water resource in arid area; eco-hydrological process; climate change in arid region; resource development and environmental improvement. E-mail: chenyn@ms.xjb.ac.cn 
Haeberli et al., 2007), but they also serve as a solid reservoir for regional freshwater resources (Sorg et al., 2012). The Tianshan Mountains, with its status as one of Central Asia's main water towers (Farinotti et al., 2015), is the seventh largest mountain range and boasts one of the most developed glacier mountains in the world (Sorg et al., 2012). It contains 10,778 glaciers having a total area of $13,566.6 \mathrm{~km}^{2}$ (http://www.glims.org/RGI/index.html). These glaciers are a critical component of the water resource in Central Asia (Zhao et al., 2015; Chen et al., 2017), and play a crucial role in the region's ecological security as well as its economic and social development (Armstrong, 2010; Sorg et al., 2012).

However, in the past half-century, temperatures around the world have increased significantly and alpine glaciers have been in retreat (Haeberli et al., 2000; Farinotti et al., 2015). In fact, the total glacier area of China has decreased by about 5.5\% (Li et al., 2008). The Tianshan Mountain range is no exception to the global rule, with approximately $97.52 \%$ of its glaciers decreasing in spatial extent (Chen et al., 2016), and showed a continue shrinking trend (Hagg et al., 2013; Farinotti et al., 2015; Petrakov et al., 2016), especially since the 1970s (Shangguan et al., 2009; Sorg et al., 2012; Pieczonka and Bolch, 2015; Kaldybayev et al., 2016). The strongest annual area shrinkage rates since the middle of the 20th century were found in the outer ranges of the Tianshan Mountains were about $0.38 \%-0.76 \% \mathrm{yr}^{-1}$, compared to the inner ranges, about $0.05-0.31 \% \mathrm{yr}^{-1}$ (Sorg et al., 2012), the volume of glaciers has decreased by about $27 \pm 15 \%$ over the past half century (Farinotti et al., 2015). In the short term, because of the ample quantities of water supplied by retreating glaciers and increased precipitation, the runoff of the rivers which were mainly fed by the glacier meltwater has increased significantly. (Pan et al., 2012; Wang et al., 2012).

The Aksu River originates in Central Tianshan Mountains and is the primary water supplier for the Tarim River mainstream in Northwest China, comprising 73.2\% of the river's volume (Fan et al., 2014). The Aksu River also plays an important role in the economic and human well-being of the Tarim River Basin region (Ouyang et al., 2007). Amidst a backdrop of accelerating global warming over the past half-century, the water cycle has intensified, particularly in these regions dominated by glacier and snow, some of the smaller glaciers rapidly shrinking or even disappeared. The Aksu River is one of the typical rivers where glacier and snow meltwater constitute the primary water source. In fact, the glacier meltwater of the river's runoff accounts for more than 50\% (Liu et al., 2006), and the glacier meltwater of the mountains is the main source of the Aksu River. With a rising of temperature, how does climate change affect the spatio-temporal change of glaciers of the Aksu River Basin? It is unclear how the depletion of glacier reserves will affect future changes in river runoff. Thus, there is a growing need to monitor and research the glaciers of this region, and to provide an accurate assessment of glacier changes, including their influence on river runoff. It plays an important role in the development of oases and sustainable use of water resources of this region. In this study, we analyzed glacier changes in the Aksu River Basin, for the periods 1975-1990, 1990-2000 and 2000-2016, based on Landsat imagery and the CGI. We used the band ratio threshold (TM3/TM5 for TM/ETM+ and TM4/TM6 for OLI) and visual interpretation to produce glacier outlines, and combined temperature and precipitation data to deepen our investigations. The aim of this study is to provide a scientific basis for the scientific management of water resources. 


\section{Study area}

The Aksu River basin, which is situated in Central Asia, in the central region of Tianshan Mountains, covering an area measuring $5.0 \times 10^{4} \mathrm{~km}^{2}$, of which the territory in Chinese area occupies $3.1 \times 10^{4} \mathrm{~km}^{2}$ and the area of Kyrgyzstan is $1.9 \times 10^{4} \mathrm{~km}^{2}$ (Figure 1). The river has two mainstreams originating from Kyrgyzstan-the Kumalak and Toxkan rivers. The Kumalak River is the north branch of the Aksu River, it originates from the Hantengri Mountains (6995 m a.s.1.) and is $293 \mathrm{~km}$ long. The Kumalak River hosts the Xiehela hydrologic station at its upper reaches and covers a catchment area of $1.28 \times 10^{4} \mathrm{~km}^{2}$. The Toxkan River is the west branch of the Aksu River, it originates from the Artbash Mountains, and is $457 \mathrm{~km}$ long, and has the Shaliguilank hydrologic station at its upper reaches. The Toxkan River Basin covers a catchment area of $1.84 \times 10^{4} \mathrm{~km}^{2}$. The Kumalak and Toxkan rivers join at Awati and finally flow to the Tarim River, $132 \mathrm{~km}$ long (Ouyang et al., 2007).

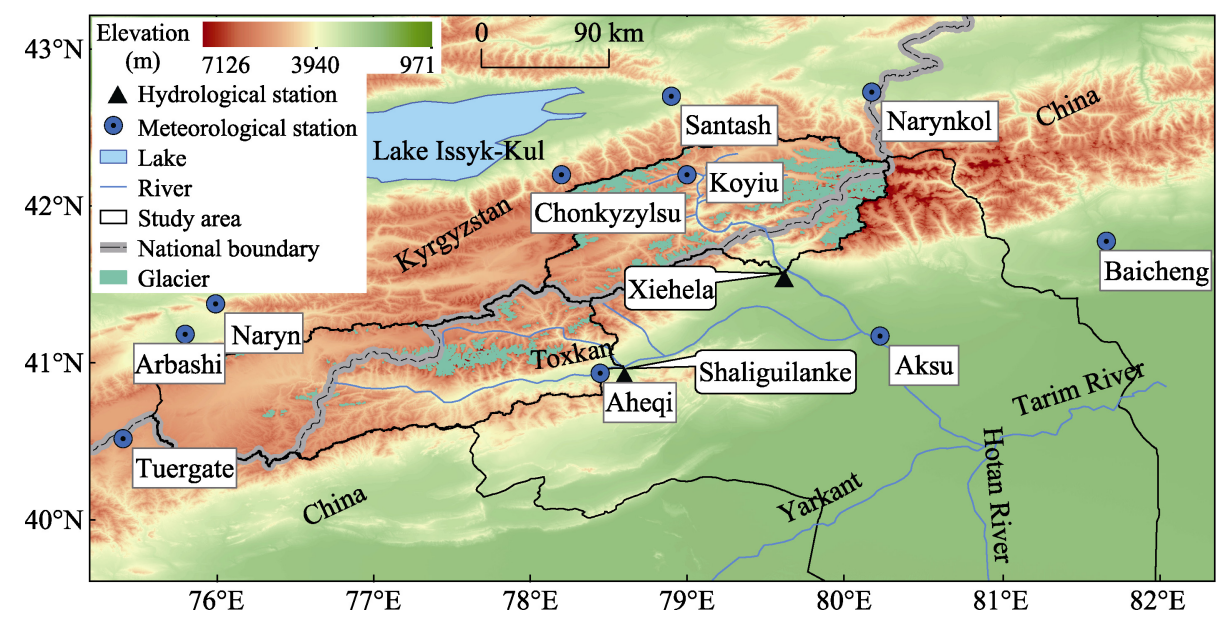

Figure 1 Location of the Aksu River Basin

The study area is characterized by its vast size, notable variations, and complex terrain, it mainly consists of mountains and plains. The terrain of the entire basin declines gradually from west to east and from north to south, with distinct geo-morphological zoning from high to low and an average elevation of $2233 \mathrm{~m}$. The Aksu River Basin experiences drought conditions that are typical for a temperate continental climate. The multi-year average annual temperature, precipitation and potential evaporation in the plain area, respectively, are about $9.2^{\circ} \mathrm{C}, 64 \mathrm{~mm}$ and $1890 \mathrm{~mm}$ (Xu et al., 2011). Moreover, with uneven spatial distribution, the vertical zonality of the basin is quite obvious. The high-mountain zone features low temperatures, high levels of precipitation, and abundant snow and ice where the precipitation reaches $900 \mathrm{~mm}$ above the snow line. The mid-mountain zone has distinct spatial variations in temperature and extensive precipitation distribution (Fan et al., 2014), while the low-mountain zone is extremely dry and features high temperatures, abundant solar radiation, less precipitation, and strong potential evaporation (Krysanova et al., 2014).

\section{Data and methods}

\subsection{Data}

Landsat scenes were chosen to analyze glacier change in the Aksu River Basin, including 
Landsat MSS/TM/ETM+/OLI and CGI. Twenty-one good quality Landsat MSS/TM/ETM+/OLI scenes were downloaded from USGS (United States Geological Survey, http://www.usgs.gov) (Table 1). All of the scenes were acquired during ablation period (from July to September, mainly in mid-August) with minimal cloud cover or nearly cloud free conditions were chose in this study to reduce potential uncertainty in glacier boundary delineation. The scenes provided by USGS were processed to Standard Terrain Correction (Level 1T), having achieved systematic radiometric and geometric accuracy. Landsat MSS, TM and ETM+ scenes were co-registered to the 2016 Landsat OLI scenes, and root-mean-square error (RMSE) was within \pm 0.5 pixel. The glacier measurements from the CGI were measured and interpreted by stereophotogrammetry from aerial photographs taken in 1966 at a scale of 1:60,000, which had been corrected based on field investigations and aerial photographs. The errors estimated for the first CGI are in the range of $\pm 0.5 \%$ to $\pm 1 \%$ (Shi, 2008).

Table 1 Remote sensing image data of Landsat images

\begin{tabular}{|c|c|c|c|c|}
\hline Period & Data & Path/Row & Satellite sensor & Spatial resolution \\
\hline \multirow[t]{4}{*}{1975} & 1977-08-18 & $158 / 31$ & Landsat MSS & \multirow{4}{*}{$\begin{array}{c}80 \mathrm{~m} \\
(\text { Channels } 4-6,7)\end{array}$} \\
\hline & $1975-08-12$ & $159 / 31$ & Landsat MSS & \\
\hline & $1975-08-13$ & $160 / 31$ & Landsat MSS & \\
\hline & $1975-08-13$ & $160 / 32$ & Landsat MSS & \\
\hline \multirow[t]{6}{*}{1990} & 1990-08-02 & $146 / 31$ & Landsat TM & \multirow{6}{*}{$\begin{array}{c}30 \mathrm{~m} \\
(\text { Channels 3-5, 7) }\end{array}$} \\
\hline & $1989-08-22$ & $147 / 31$ & Landsat TM & \\
\hline & 1991-08-19 & $148 / 31$ & Landsat TM & \\
\hline & 1991-08-19 & $148 / 32$ & Landsat TM & \\
\hline & 1990-08-07 & $149 / 31$ & Landsat TM & \\
\hline & 1990-08-07 & $149 / 32$ & Landsat TM & \\
\hline \multirow[t]{5}{*}{2000} & $2003-07-29$ & $146 / 31$ & Landsat ETM+ & \multirow{5}{*}{$\begin{array}{c}15 / 30 \mathrm{~m} \\
(\text { Channels } 3-5,7)\end{array}$} \\
\hline & $1999-08-26$ & $147 / 31$ & Landsat ETM+ & \\
\hline & 1999-09-18 & $148 / 31$ & Landsat ETM+ & \\
\hline & 1999-09-18 & $148 / 32$ & Landsat ETM+ & \\
\hline & 1999-08-16 & $149 / 32$ & Landsat ETM+ & \\
\hline \multirow[t]{6}{*}{2016} & 2016-08-09 & $146 / 31$ & Landsat OLI & \multirow{6}{*}{$\begin{array}{c}15 / 30 \mathrm{~m} \\
(\text { Channels } 4-6,7)\end{array}$} \\
\hline & 2016-09-01 & $147 / 31$ & Landsat OLI & \\
\hline & $2015-08-21$ & $148 / 31$ & Landsat OLI & \\
\hline & 2016-09-08 & $148 / 32$ & Landsat OLI & \\
\hline & 2015-08-12 & $149 / 31$ & Landsat OLI & \\
\hline & $2015-08-12$ & $149 / 32$ & Landsat OLI & \\
\hline
\end{tabular}

For DEM, we used a digital elevation model (DEM), from the Shuttle Radar Topography Mission (SRTM), with a spatial resolution of $90 \mathrm{~m}$. The accuracy of SRTM DEM is specified within $20 \mathrm{~m}$ in xy-directions and $16 \mathrm{~m}$ in the $\mathrm{z}$-direction, with a $90 \%$ confidence coefficient (Falorni et al., 2005). Flat areas in particular can show a RMSEz below $10 \mathrm{~m}$, whereas steep slopes may have even higher elevation errors (Rodríguez et al., 2006).

The terminus elevation of the glaciers was above $3200 \mathrm{~m}$, and the meteorological stations chosen in our study were located between 1104-3504 m. Climate data of the study area in 
China were obtained from the National Climate Centre, China Meteorological Data Service Center (CMDC, http://data.cma.cn/en) as annual and monthly dataset of temperature and precipitation for the period 1960-2016. The climate data from the Shaliguilanke (1909 m) and Xiehela $(1427 \mathrm{~m}$ ) hydrologic station were provided by the Xinjiang Tarim River Basin Management Bureau during 1975-2000. And the observed stations (between 1806-2800 m) in Kyrgyzstan (Figure 1) were obtained from the National Snow and Ice Data Center (NSIDC, ftp://sidads.colorado.edu/pub/DATASETS/NOAA/G02174/) during the period 1960-2003. According to the temperature of meteorological stations at different elevations, we found that every increase of $120-140 \mathrm{~m}$ in altitude will lead to a drop of temperature by $1{ }^{\circ} \mathrm{C}$.

\subsection{Methods}

\subsubsection{Extraction of glacier information}

At present, there are several different remote sensing methods for acquiring glacier information, these include band ratio thresholding (Bolch, 2007; Kaldybayev et al., 2016), supervised and non-supervised classification (Sidjak, 1999), the normalized difference snow index (NDSI) (Willmes et al., 2009), the decision tree classifier (Racoviteanu and Williams, 2012), the object-oriented image interpretation, principal components analysis (Hagg et al., 2013), among others. The presence of snow, shadowing, moraines and water interferes with the process of data-gathering at glacier sites, making it difficult to ensure the accuracy of the information being extracted. The band ratio threshold method is an efficient and time-effective approach for distinguishing glaciers from clouds and shadows (Kaldybayev et al., 2016). In addition, we displayed the multispectral scenes in a color combination that emphasizes the difference between glaciers (snow and ice) and non-glaciers.

Glacier outlines were delineated based on Landsat scenes from 1975, 1990, 2000 and 2016 (Table 1). We first used the band ratio technique (TM3/TM5 and TM4/TM6) with a threshold of 2.1 to reclassify glaciers and non-glaciers, misclassified areas (e.g. snow patches, cast shadows and lakes) had to be corrected manually using multispectral band combinations (MSS bands 4, 6 and 7; TM/ETM+ bands 3, 5 and 7; OLI bands 4, 6 and 7) on Landsat imagery. Glacier mapping by spectral band combinations is regarded as one of the most efficient methods of mapping debris-free glaciers (Kaldybayev et al., 2016), but it is not suitable for debris-covered glaciers (Pan et al., 2012). Due to the limitations of this method, the outlines of several debris-covered glaciers in the Aksu River Basin were difficult to extract (Huai et al., 2015). In these cases, visual interpretation was applied using characteristics and cues such as terminal moraines, the heads of glacier meltwater, glacial lakes and lateral moraines. In utilizing the process of remote sensing scenes to extract glacier outlines and replace anomalies and artifacts, we re-sampled the SRTM data to $30 \mathrm{~m}$ and then used the ridge line (extracted from the plane curvature and the slope-shape combination watershed hydrology method) to extract the glacier outlines.

The Landsat MSS scenes have a comparatively low resolution $(80 \mathrm{~m})$, which is less accurate than TM/ETM+ and OLI scenes, especially for glaciers that are relatively small in area and are debris-covered. Similar problems have been reported by Pieczonka et al. (2015), Li et al. (2006) in Central Tianshan Mountains, Yu et al. (2015) in eastern Altun Mountains, and Pan et al. (2012) in Gongga Mountains. Despite these issues, Landsat MSS scenes re- 
main an important resource, since they are available in most parts of Central Asia and provide some of the only pertinent data extending from the 1970s (Li et al., 2006; Pieczonka and Bolch, 2015; Yu and Lu, 2015). Landsat MSS data from 1975-1977 were used in this study to extract glacier outlines in the 1970s. CGI was used as supplementary data to obtain and correct the glacier information in some areas with difficult mapping conditions. Meanwhile, in order to reduce any uncertainty arising from the extraction of glacier boundaries, it is also supported by high-resolution images of Google Earth during the process of glacial boundary extraction.

As mentioned above, uncertainties in glacier mapping are an ongoing issue. For instance, frozen water bodies, clouds, snowfields, debris cover and shadows are unavoidable factors (Barry, 2006; Gardner et al., 2013; Kaldybayev et al., 2016) affecting the accuracy of glacier outline maps. In the Aksu River Basin, the refreezing water did not occur during the ablation time, so this factor is neglected. Furthermore, in analyzing the Landsat scenes used in this region, we noted that there are few clouds in the 1975 and 2016 scenes, and only a few clouds in the 1990 and 2000 scenes. When clouds were present, we used the best available alternative scenes from the nearest years. Supraglacial debris cover can be a major factor reducing the accuracy of glacier outlines. However, only about $5 \%$ of the glacier surfaces in our study area are debris-covered (Duethmann et al., 2015; Pieczonka and Bolch, 2015). Additionally, misclassified areas such as cast shadows, lakes, debris and seasonal snow cover were manually edited out. Meanwhile, in order to reduce the uncertainty of the extraction of glacier boundaries to the greatest extent possible, Google Earth was also supported.

\subsubsection{Changes in glacier area of various size classes}

Because the scale of glacier development in the study area differs in region, we choose the standard $0.01 \mathrm{~km}^{2}$ as the minimum glacier area (Kaldybayev et al., 2016). Based on this standard, the glaciers in the Aksu River Basin were divided into 11 classes, as follows: (1) $0.01-0.1 \mathrm{~km}^{2}$; (2) $0.1-0.5 \mathrm{~km}^{2}$; (3) $0.5-1 \mathrm{~km}^{2}$; (4) $1-2 \mathrm{~km}^{2}$; (5) $2-5 \mathrm{~km}^{2}$; (6) $5-10 \mathrm{~km}^{2}$; (7)

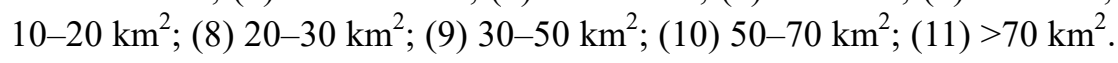

\subsubsection{Glacier volume estimation}

Changes in glacier thickness and volume has an important and direct impact on river runoff compared to glacier surface area. However, the traditional methods for measuring snow pits e.g. ground-penetrating radar (GPR) or glacier thickness can be difficult to be used when measuring a large number of glaciers due to high costs and the risks inherent in field surveys. While in regions without high quality topographical map coverage, uncertainty persists in measuring glacier thickness, and thus volume-area (VA) scaling has become a feasible alternative for assessing glacier volume variations both regionally (Nuth et al., 2010; Petrakov et al., 2016; Yu and Lu, 2015) and globally (Barry, 2006). This approach offers the simplest method for roughly estimating the glacier volume changes from glacier areas ( $\mathrm{Yu}$ and $\mathrm{Lu}$, 2015). In VA scaling, the ice volume is calculated as a function of area. Equation (1) shows the general form of VA scaling:

$$
V=C S^{r}
$$

where $V$ is glacier volume $\left(\mathrm{km}^{3}\right), S$ is glacier area $\left(\mathrm{km}^{2}\right), C$ and $r$ are the scaling coefficient, the density of ice is $0.9 \mathrm{~g} / \mathrm{cm}^{3}$. In this study, we used two volume-area scalings, with $\mathrm{C}=$ 0.0365 and $\mathrm{r}=1.375$ (Radić and Hock, 2010) and $\mathrm{C}=0.0433, \mathrm{r}=1.29$ (Grinsted, 2013) to estimate the volumes of all study glaciers. 


\subsubsection{Glacier terminus change}

Glacier terminus change is one of the most important indicators of glacier change (Pieczonka et al., 2013). Due to harsh environmental conditions typically present in the field, measurements are often restricted, so remote sensing is used to measure glacier terminus. Remote sensing scenes are usually based on differences between the length of the longest axes (i.e., the length of the main line) (Machguth and Huss, 2014). However, some glaciers have a complex form (e.g. more than one glacier terminus), which results in inaccurate recording of changes in glacier length. According to the planar characteristics of remote sensing images on glaciers, and by using remote sensing images, we used GIS technology and the principles of geographical statistics to improve the method (i.e., the main method of parallel lines) for measuring glacier length and thus discerning glacier changes in the Aksu River Basin (Nie et al., 2010).

The main method of parallel lines keeps the longest axis parallel to the line-cutting end of the glacier and uses the average value of each segment change. The equation is as follows:

$$
G r s=\sum_{i=1}^{n}\left(L_{i-t_{2}}-L_{i-t_{1}}\right) / n\left(t_{2}-t_{1}\right)
$$

where Grs is the mean rate of glacier retreat; $L_{i-t_{2}}$ is the glacier length of the line $i$ in $t_{2}$ year; $t_{1}$ and $t_{2}$ are the first year and last year of the scenes (unit: year), respectively, and $n$ is the glacier number. (Note that we used five parallel lines in the article.)

\section{Results}

\subsection{Spatio-temporal changes of glacier}

We mapped 2506 glaciers in the Aksu River Basin, covering a total area of $2765.54 \mathrm{~km}^{2}$ in 2016, about $8.92 \%$ of the total basin catchment area. The glacier area of the Kumalak River Basin was about $2091.81 \mathrm{~km}^{2}$, about $16.34 \%$ of the catchment area, and the glacier area of the Toxkan Basin was $673.73 \mathrm{~km}^{2}$, about $3.66 \%$ of the catchment area.

We analyzed glacier changes in the Aksu River Basin during 1975-2016, discovering that the glaciers in the region showed significant recession (Figure 2 and Table 2). Specifically, in 1975 , the total glacier area of the basin was about $3731.24 \mathrm{~km}^{2}$, but by 2016 , this area had shrunk to $2765.54 \mathrm{~km}^{2}$, a decrease of $965.7 \mathrm{~km}^{2}(25.88 \%)$, with a rate of $23.55 \mathrm{~km}^{2} \mathrm{yr}^{-1}$. Overall, the total glacier number dropped from 2708 to 2506 , these including many smaller glaciers that were split by larger glaciers or disappeared altogether due to melting. In 1975, the total glacier volume in the basin was about $307.98-331.08 \mathrm{~km}^{3}$, but by 2016 , this volume had shrunk to $233.13-252.56 \mathrm{~km}^{3}$, this represents a decrease of $74.85-78.52 \mathrm{~km}^{3}$, and a reduction of about $1.83-1.92 \mathrm{~km}^{3} \mathrm{yr}^{-1}\left(0.58-0.59 \% \mathrm{yr}^{-1}\right)$.

\subsubsection{Changes in glacier areas}

As shown in Figure 2, the vast majority of glaciers in the Aksu River Basin were classified as small glaciers $\left(<1 \mathrm{~km}^{2}\right)$, about $74.26 \%$ of the total glacier number but only contributed to $21.49 \%$ of the total glacierized area. The glaciers $\left(>1 \mathrm{~km}^{2}\right)$ comprised only $25.74 \%$ of the total glacier number, but these contributed $78.51 \%$ of the total glacierized area.

Over the past 41 years, we identified that the number of the glaciers with sizes $<1 \mathrm{~km}^{2}$ had increased by $60(2.98 \%)$, while the glacier area decreased by $143.12 \mathrm{~km}^{2}(19.42 \%)$ 


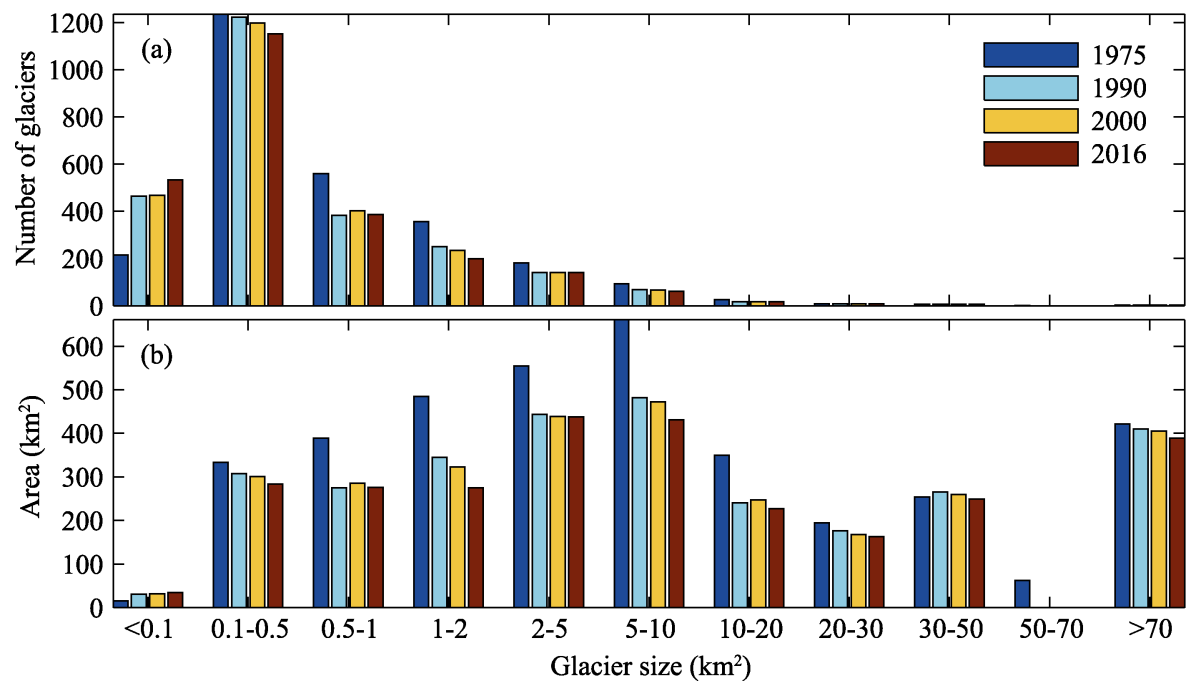

Figure 2 Changes in glacier number and area in the Aksu River Basin from 1975 to 2016

(Table 2). The number of glaciers $>1 \mathrm{~km}^{2}$ had been reduced by $240(35.66 \%)$ and the glacier area had been decreased by $27.4 \%$. Meanwhile, the number of glaciers measuring $\geq 20 \mathrm{~km}^{2}$ did not change significantly, mainly reduced by their thickness and the glacier area had decreased by $14.92 \%$. The variations in glacier number and areas indicate that the small glaciers are generally more sensitive to climate change.

Table 2 Changes in glacier area according to various glacier sizes of the Aksu River Basin from 1975 to 2016

\begin{tabular}{lccccccccccc}
\hline Interval area $\left(\mathrm{km}^{2}\right)$ & $0.01-0.1$ & $0.1-0.5$ & $0.5-1$ & $1-2$ & $2-5$ & $5-10$ & $10-20$ & $20-30$ & $30-50$ & $50-70$ & $>70$ \\
\hline Number change & 317 & -84 & -173 & -156 & -41 & -31 & -10 & -1 & 0 & -1 & 0 \\
Number change (\%) & 147.44 & -6.80 & -30.89 & -43.94 & -22.53 & -33.70 & -38.46 & -12.50 & 0 & -100 & 0 \\
Area change (\%) & 131.58 & -14.72 & -29.20 & -43.20 & -21.06 & -34.76 & -35.25 & -16.17 & -1.71 & -100 & -7.63 \\
\hline
\end{tabular}

\subsubsection{Changes in glaciers at different elevations}

Based on glacier polygons and SRTM-DEM, we investigated the changes in glaciers at different elevations during 1975-2016. The glaciers are mainly located at 3900-4000 m, $4000-4100 \mathrm{~m}, 4100-4200 \mathrm{~m}$ and $4200-4300 \mathrm{~m}$, with their altitude range accounting for $12.02 \%, 18.54 \%, 20.33 \%$ and $14.82 \%$, respectively, for a total of $65.69 \%$.

In analyzing the trend of advancing and retreating glaciers at different altitudes, we found the glaciers below $4100 \mathrm{~m}$ showed a significant retreat. For example, the decrease rates of glaciers at $3300-3400 \mathrm{~m}, 3400-3500 \mathrm{~m}, 3500-3600 \mathrm{~m}, 3600-3700 \mathrm{~m}, 3700-3800 \mathrm{~m}$, $3800-3900 \mathrm{~m}, 3900-4000 \mathrm{~m}$ and $4000-4100 \mathrm{~m}$ were $57.14 \%, 81.82 \%, 61.76 \%, 69.89 \%$, $54.19 \%, 27.48 \%, 22.02 \%$ and $12.62 \%$, respectively. Of these, the glaciers below 3,700 m showed the greatest retreat, accounting for $54.4 \%$ of the total glacier number reduction. The glacier number above $4,100 \mathrm{~m}$ showed obviously increase, these increased glaciers at $4100-4200 \mathrm{~m}, 4200-4300 \mathrm{~m}, 4300-4400 \mathrm{~m}$ and $4400-4500 \mathrm{~m}$ were $58(12.86 \%), 34$ (10.09\%), 42 (20.29\%) and 60 (72.29\%), respectively. By 2016, all glaciers below $3250 \mathrm{~m}$ had completely disappeared. The terminus elevation of the glaciers in the Aksu Basin was $4078.26 \mathrm{~m}$ in 1975 , this jumped to $4146.11 \mathrm{~m}$ by 2016 , which marks an increase in elevation of nearly $67.85 \mathrm{~m}$. Overall, the median elevation of glaciers increased by $36.09 \mathrm{~m}$ over the past 41 years. 
A comparative analysis of different elevations and glacier classes showed that glaciers in area under study region had generally receded (Figure 3), with glacier area measured 0.1-2 $\mathrm{km}^{2}$ which situated below 4,400 m showing a significant retreat. Especially, between 1975 and 2016, glaciers measured 1-2 $\mathrm{km}^{2}$ and situated between $3800-3900 \mathrm{~m}$ and $3900-4000 \mathrm{~m}$ in elevation underwent the greatest reduction (each up to 44), while the glacier number and area of the glaciers measured $0.01-0.1 \mathrm{~km}^{2}$ and situated at $3800-4600 \mathrm{~m}$ experienced an increase of $59.05 \%$ and $131.59 \%$, respectively. We found this resulted from the glaciers $>$ $0.1 \mathrm{~km}^{2}$ at these elevations retreated and ruptured. The characteristics of glaciers at different elevations indicate that with the increased temperature in the Tianshan Mountain area, the elevation of the glacier terminus in the Aksu River Basin is obviously rising.

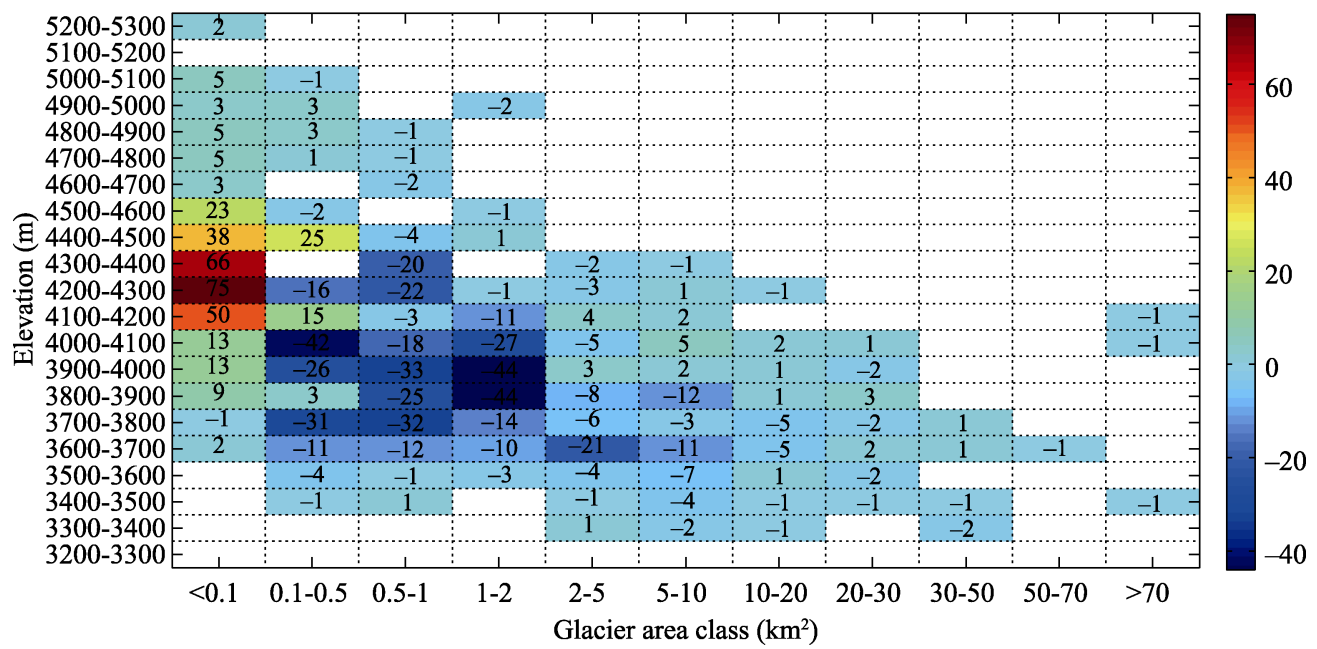

Figure 3 Changes in glacier number by glacier class and elevation during 1975-2016. The color bar shows the number change of glaciers, the blue color shows the decrease number and the red color shows the increase number.

\subsubsection{Glacier changes by sector}

Further analysis of regional characteristics of glacial distributions in the Aksu River Basin from 1975-2016 indicated that the majority of the glaciers were north-facing (northwest, north, and northeast), with a glacier area of $1413.65 \mathrm{~km}^{2}$, accounting for $51.12 \%$ of the total glacier area (Figures $4 \mathrm{a}$ and $4 \mathrm{~b}$ ). Furthermore, all aspects showed a reduction in glacier area during 1975-2016, but the largest area changes occurred on the northeast aspect, decreased by $165.78 \mathrm{~km}^{2}$ or $17.27 \%$ of the glacier area. The glaciers on the east, northeast, south and southeast aspects showed a remarkable reduction in glacier area, about 35\%, 31.22\%, $32.53 \%$ and $33.76 \%$, respectively, especially on the east aspect. While glaciers with aspects to the west, northwest and north showed the lowest, retreating by $0.57 \% \mathrm{yr}^{-1}, 0.45 \% \mathrm{yr}^{-1}$ and $0.50 \% \mathrm{yr}^{-1}$, respectively.

In comparison of the aspects of glacier area and relative changes of different sub-basins (Figures $4 \mathrm{~b}$ and 4c), the glacier area in the Kumalak and Toxkan river basins was mainly concentrated in the north (northwest, north and northeast) and accounted for approximately $53.26 \%$ and $61.84 \%$ of the sub-basin glacier area. We found that the glaciers in the east, northeast and southeast of the Aksu River Basin underwent significant retreat, and the glaciers in the south and southwest which are closer to the western portion of the basin showed a strongly retreat. The glaciers in the east, southeast and northeast aspects of the Kumalak 
River Basin showed the strongly retreat, the glacier area reduced by $37.68 \%, 34.35 \%$ and $34.15 \%$, respectively. While in the Toxkan River Basin, the largest area changes occurred on the south, southwest and southeast aspects, reduced by $34.92 \%, 34.05 \%$ and $31.55 \%$.

(a)
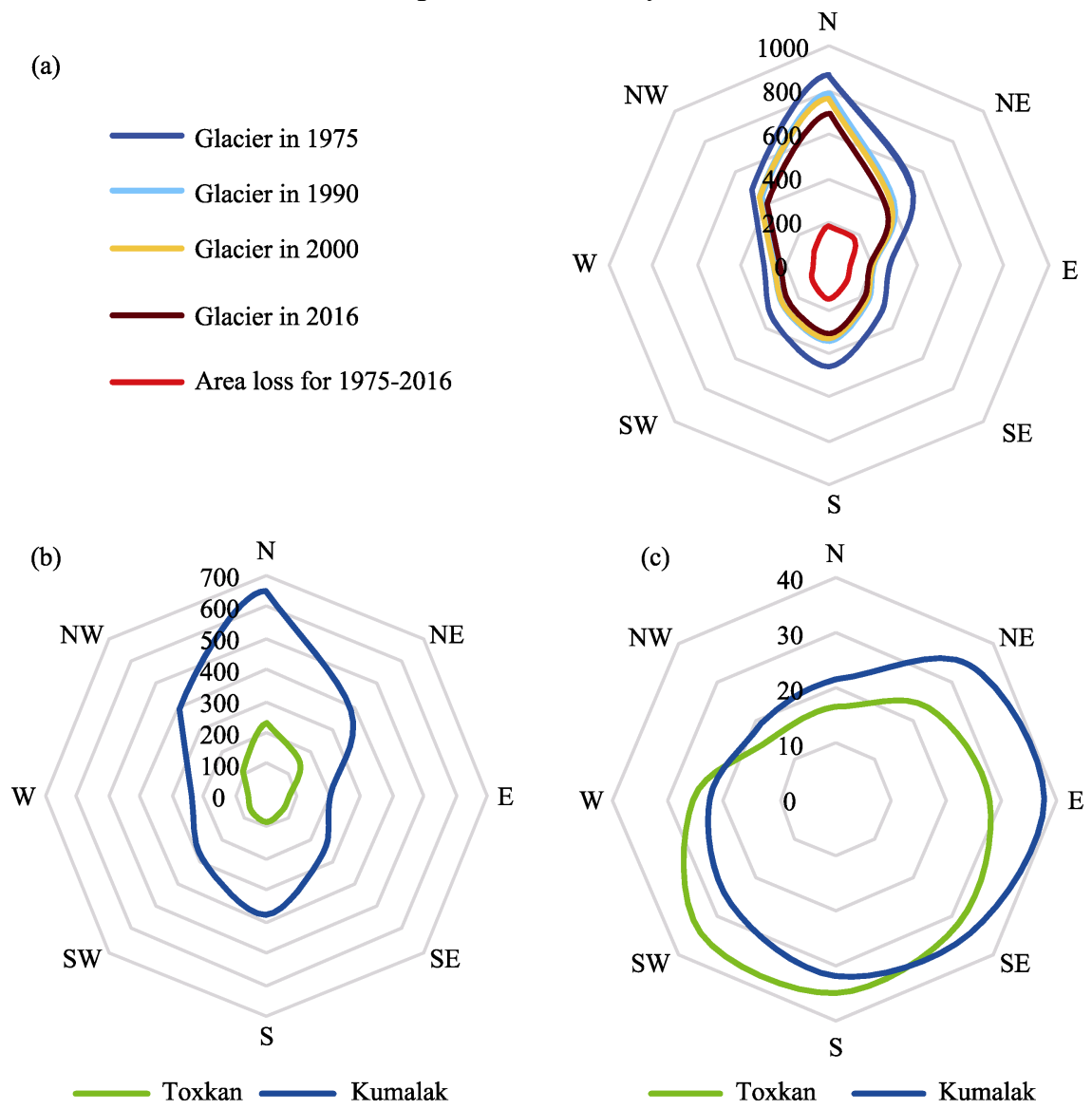

Figure 4 Distribution of glacier areas and their changes according to aspect in the Aksu River Basin and sub-basins during 1975-2016 (a. Glacier area changes in the Aksu Basin; b. Distribution of glacier areas in different Aksu sub-basins in 1975; c. Relative changes in glacier areas in different Aksu sub-basins)

From further analysis of the regional characteristics of glacial distributions and changes, we found that the precipitation of the basin was mainly supplied by the westerly airflow and the warm and wet flow which originated from the Arctic Ocean (Krysanova et al., 2014). Hence, the precipitation on the north aspect was larger than that on the south of the mountains. Meanwhile, the north aspect received less solar radiation than the south, these areas were thus more conducive to glacier development, and made the majority of the glaciers concentrated in the north aspect (Lai et al., 1986). Moreover, we identified that the differences among glacier rates of different aspects were mainly affected by solar radiation, rainfall, wind and terrain, and the differences on glacier scale of different aspects will also affect the glacier change to some extent.

\subsection{Regional differences in glacier changes}

\subsubsection{Regional differences of glacier distribution}

The results showed that there had significant regional differences in distribution of glaciers 
between the Toxkan and Kumalak river basins (Figures 1, 4 and Table 3). The glaciers in the Aksu River Basin were mainly concentrated in the Kumalak River Basin, where the glaciers were relatively concentrated and large in scale, and the glacier number and area accounted for $63.15 \%$ and $76.47 \%$ of the former. The mean area of each glacier was about $1.36 \mathrm{~km}^{2}$, while in the Toxkan River Basin, only $0.69 \mathrm{~km}^{2}$. In terms of the proportion of glaciers in the sub-basins, the glacier area in the Kumalak River Basin was the highest, about $22.3 \%$ of the basin area. Although the boundary area of the Toxkan River Basin was larger, the proportion of glacier area didn't exceed 5\% in any period. The results showed that the glacier scale and area of the basin had an important influence on the hydrological process of the river.

Table 3 Glacier changes in the Aksu River Basin in different periods from 1975 to 2016

\begin{tabular}{|c|c|c|c|c|c|c|c|c|}
\hline \multirow{2}{*}{ Sub-basin } & \multicolumn{4}{|c|}{ Glacier number } & \multicolumn{4}{|c|}{ Glacier area proportion $(\%)$} \\
\hline & 1975 & 1990 & 2000 & 2016 & 1975 & 1990 & 2000 & 2016 \\
\hline Toxkan & 998 & 968 & 971 & 970 & 4.77 & 3.90 & 3.87 & 3.66 \\
\hline Kumalak & 1710 & 1597 & 1572 & 1536 & 22.30 & 17.62 & 17.32 & 16.34 \\
\hline Total & 2708 & 2565 & 2543 & 2506 & 12.04 & 9.59 & 9.45 & 8.92 \\
\hline
\end{tabular}

\subsubsection{Regional differences of glacier change}

Since 1975, the glaciers in the Aksu River Basin have shown a shrinking trend, however, the different sub-basins had a big difference in glacier area change. Compared to the glacier development, a shrinkage of $26.7 \%$ occurred in the Kumalak River Basin which was higher than that of the Toxkan River Basin, at a rate of $23.26 \%$. We found that the elevations of the Kumalak River Basin range from 2000 to 7400 $\mathrm{m}$. The peak is Tuomuer (up to $7435 \mathrm{~m}$ ) and the average elevation of the basin is about $3820 \mathrm{~m}$, these altitudes were conducive to glacier development. Thus, we found the average elevation of the glacier terminus in the Kumulak River Basin was 4087.9 m. In slight contrast, the elevation of the Toxkan River Basin ranges from 1800 to $5600 \mathrm{~m}$, with the average glacier terminus situated at $4238.29 \mathrm{~m}$. That is why the average elevation of the glacier terminus in the Kumalak River Basin is lower than that of the Toxkan River Basin, which made the glaciers in the former particularly more sensitive to climate change with more obvious glacier retreat. Over the past 41 years, the average and median elevation of glacier terminus of the western Toxkan River Basin had increased by $67.42 \mathrm{~m}$ and $36.62 \mathrm{~m}$, respectively, while the eastern Kumalak River Basin increased by $63.69 \mathrm{~m}$ and $33.08 \mathrm{~m}$, respectively.

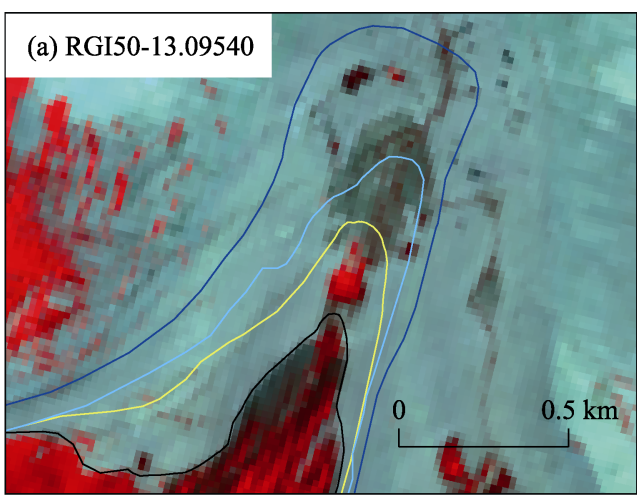

(b) RGI50-13.04920

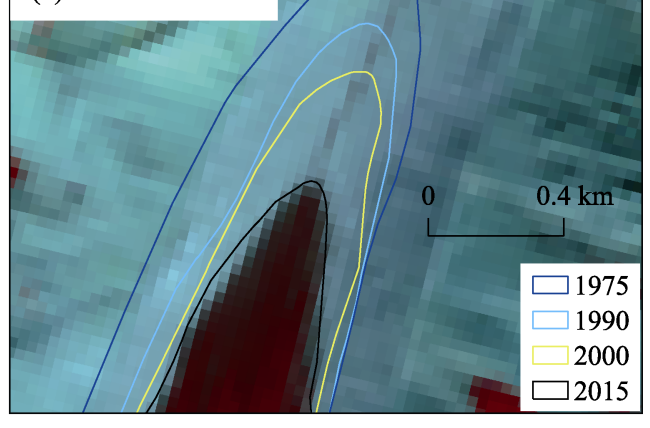

Figure 5 Terminus retreat of the typical glaciers in the Aksu River Basin since 1975 


\subsubsection{Changes of glacier retreat}

Four intervals and two typical glaciers (the RGI50-13.09540 glacier in the Toxkan River Basin and the RGI50-13.04920 glacier in the Kumalak River Basin) were selected using Landsat MSS/TM/ETM+/OLI scenes during the period 1975-2016. These were combined with the CGI to extract typical glacier length. The results showed that the terminus of the RGI50-13.09540 glacier (the glacier ID of Randolph Glacier Inventory, RGI) retreated about

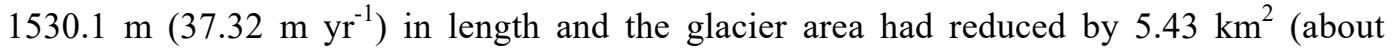
$0.64 \% \mathrm{yr}^{-1}$ ) from 1975 to 2016 (Figure 5 and Table 4). While the shrinkage of RGI50-13.04920 glacier in the Kumalak River Basin showed a retreat of $660.22 \mathrm{~m}$ (about $16.1 \mathrm{~m} \mathrm{yr}^{-1}$ ), with the glacier area had reduced by $1.9 \mathrm{~km}^{2}$ (about $0.48 \% \mathrm{yr}^{-1}$ ). Meanwhile, regional glacier shrinkage varied with elevation (hypsography), we found glaciers located in the lower elevation shrank more strongly by comparing the glacier changes. For example, the terminus of the RGI50-13.09540 glacier whose elevation was above $3800 \mathrm{~m}$ of the Toxkan River Basin rose by about $47 \mathrm{~m}$ over the past 41 years, while the RGI50-13.04920 glacier whose elevation of the terminus was about $3500 \mathrm{~m}$, rose by about $77 \mathrm{~m}$ and the terminus of it retreated about $12.87 \%$.

Table 4 Terminus retreat of the typical glaciers in the Aksu River Basin

\begin{tabular}{|c|c|c|c|c|c|c|c|c|c|c|}
\hline \multirow{2}{*}{ Glacier ID } & \multirow{2}{*}{ Sub-basin } & \multicolumn{3}{|c|}{ Length change } & \multicolumn{3}{|c|}{ Area change } & \multicolumn{3}{|c|}{ Terminus change } \\
\hline & & $\mathrm{m}$ & $(\%)$ & $\mathrm{m} \mathrm{yr}^{-1}$ & $\mathrm{~km}^{2}$ & $(\%)$ & $\mathrm{km}^{2} \mathrm{yr}^{-1}$ & $\mathrm{~m}$ & $(\%)$ & $\mathrm{myr}^{-1}$ \\
\hline RGI50-13.09540 & Toxkan & 1530.1 & 1.54 & 37.32 & 5.43 & 26.26 & 0.13 & 47 & 1.21 & 1.15 \\
\hline RGI50-13.04920 & Kumalak & 660.22 & 12.87 & 16.1 & 1.9 & 19.62 & 0.05 & 77 & 2.18 & 1.88 \\
\hline
\end{tabular}

Our exhaustive investigation of the glacier retreat indicated that, the rate of glacier retreat was not consistent during different periods. Combined the characteristic of climate change, our investigation indicated that, during the last 41 years, the highest glacier retreat of both RGI50-13.09540 and RGI50-13.04920 occurred in the period 1975-1990, slowed obviously during 1990-2000, about $-0.2 \% \mathrm{yr}^{-1}$ and $-0.27 \% \mathrm{yr}^{-1}$, respectively. Over the past 16 years since 2000, the rate of the RGI50-13.09540 glacier retreat became quickened, reached its rapid rate of $0.27 \% \mathrm{yr}^{-1}$, but it was still lower compared with the period 1975-1990. Meanwhile, the RGI50-13.04920 glacier retreat of the Kumalak River Basin has been slight since 1990 (Table 5).

Table 5 Glaciers retreat in the Aksu River Basin in different periods from 1975 to 2016

\begin{tabular}{|c|c|c|c|c|c|c|c|}
\hline \multirow{2}{*}{ Glacier ID } & \multirow{2}{*}{ Sub-basin } & \multicolumn{3}{|c|}{ Length change $\left(\mathrm{m} \mathrm{yr}^{-1}\right)$} & \multicolumn{3}{|c|}{ Area change $\left(\% \mathrm{yr}^{-1}\right)$} \\
\hline & & $1975-1990$ & 1990-2000 & 2000-2016 & $1975-1990$ & 1990-2000 & 2000-2016 \\
\hline RGI50-13.09540 & Toxkan & 44.36 & 35.69 & 31.74 & 1.42 & 0.2 & 0.27 \\
\hline RGI50-13.04920 & Kumalak & 10.79 & 13.95 & 22.43 & 1.02 & 0.27 & 0.15 \\
\hline
\end{tabular}

\subsection{Analysis of the driving factors of glacier change}

A glacier system is influenced by a broad range of interconnected climatic and topographic factors (e.g. elevation, aspect and slope) (Yu and Lu, 2015; Wang et al., 2017) as well as by glacier-supplying conditions (supraglacial debris cover and the size of the glacier area) (Kaldybayev et al., 2016). Among the contributing factors to glacier change, these related to climate (e.g. temperature and precipitation) (Farinotti et al., 2015; Li et al., 2006; Pieczonka et al., 
2013) may be the most important factor. Glacier change is essentially the product of climate fluctuation, with the ablation and accumulation of glaciers being controlled by the two main factors of temperature and precipitation. These two factors also affect glacier development (Pan et al., 2012).

Based on the climate data from four meteorological stations (Tuergate, Aheqi, Baicheng and Aksu) and two hydrological stations (Shaliguilanke and Xiehela) (Figures 1, 6 and 7) near the basin, we found a significant increase in temperature during the period 1975-2016. Of special note is that the temperature experienced a sharp increase in 1997, and since then has been in a state of high variability. Compared to the temperatures before 1997, the temperature has increased by $0.29-1.65^{\circ} \mathrm{C}$. The increased rate of the temperature was about $0.38^{\circ} \mathrm{C} 10 \mathrm{yr}^{-1}$, which means the temperature has increased by $1.56^{\circ} \mathrm{C}$ over the past 41 years, and the rates of temperature increased in the Shaliguilanke and Xiehela stations were about

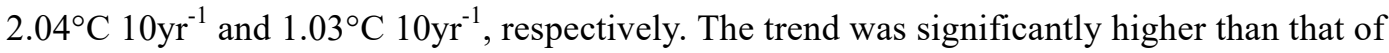
the average global warming rate, and those of the Tianshan Mountains, northwest China and Xinjiang (Table 6). The rapid increase in temperature in recent years has resulted in a prolonged melting season for glaciers and accelerated glacier retreat in summer seasons (Sorg et al., 2012; Petrakov et al., 2016).
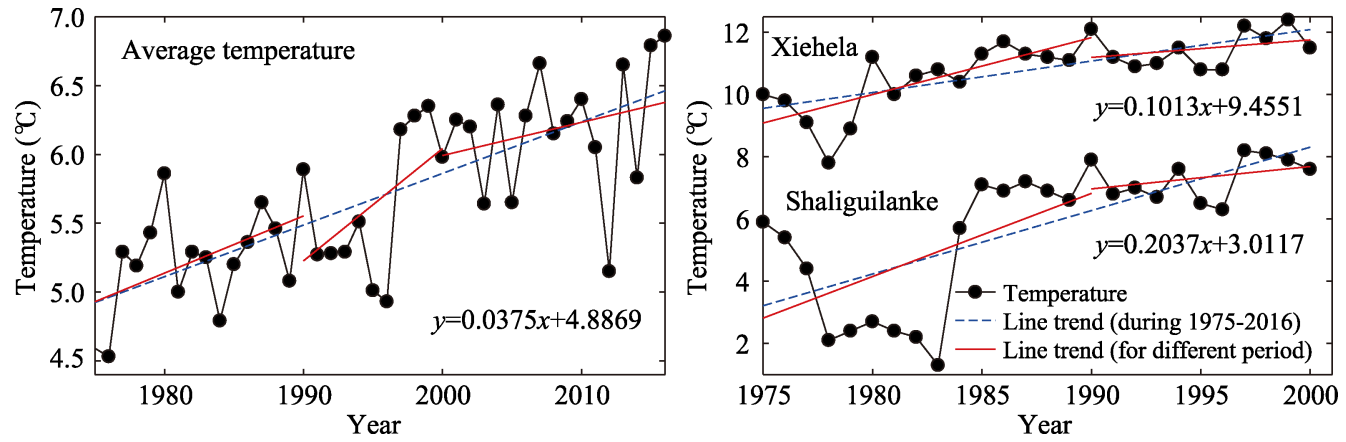

Figure 6 Variations in annual average temperature in the Aksu River Basin during 1975-2016
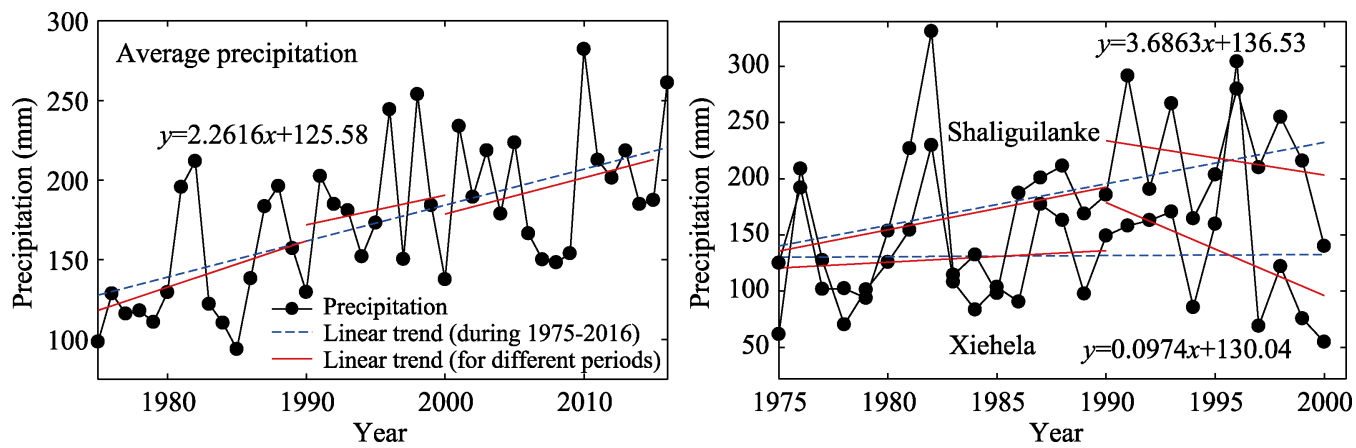

Figure 7 Variations in annual average precipitation in the Aksu River Basin during 1975-2016

Table 6 The increasing rate of temperature in different regions

\begin{tabular}{cccccc}
\hline Region & Global & Central Asia & China & Northwest China & Xinjiang \\
\hline Increasing temperature & 0.12 & $0.15-0.31$ & 0.22 & 0.34 & 0.33 \\
$\left({ }^{\circ} \mathrm{C} 10 \mathrm{yr}^{-1}\right)$ & IPCC, 2013 & Deng et al., 2017 & Ding et al., 2007 & Chen et al., 2014 & Li et al., 2012 \\
\hline
\end{tabular}


With the increased temperature, the variation of the annual average precipitation of the Aksu River Basin also showed a notable upward trend. Over the past 41 years, the annual precipitation increased by about $92.74 \mathrm{~mm}$, at a rate of $22.6 \mathrm{~mm} \mathrm{10yr}^{-1}$ (Figure 7). With the increasing altitude, the precipitation increased more significantly, for example, during 1975-2016, the annual increased rate of precipitation at the Tuergate (3504 m), Aheqi (1985 $\mathrm{m})$, Aksu $(1104 \mathrm{~m})$ and Baicheng $(1229 \mathrm{~m})$ stations increased by $37.33 \mathrm{~mm} \mathrm{10yr} \mathrm{r}^{-1}, 33.36$

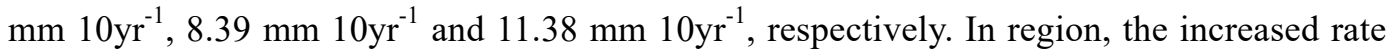
of precipitation of the western was significantly higher than that of the eastern. The precipitation of all meteorological stations showed a positive trend of increase, the precipitation

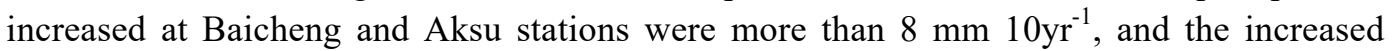

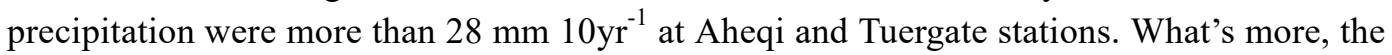

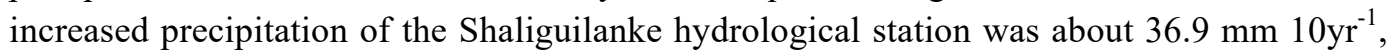
which was more remarkable.

There is a close correlation between the annual average temperature, precipitation change and glacier retreat. During the period 1975-1990, the average temperature was about $5.24^{\circ} \mathrm{C}$, $7.78 \%$ higher than the average temperature during 1960-1975, including the high-altitude stations of Tuergate $(3504 \mathrm{~m})$ and Koyiu $(2800 \mathrm{~m})$ where the average temperature increased by $12.81 \%$ and $10.37 \%$, respectively, and even the average temperature in the Atbashi station $(2320 \mathrm{~m})$ increased by about $38.49 \%$, which was more significant. The average precipitation during $1975-1990$ was the least, only about $80.39 \%$ of the average precipitation over the past 41 years (1975-2016). The average precipitation of the high altitude Tuergate station decreased by $13.98 \%$, from 1975 to 1990, while reduction in glacier area during this period was the highest (Tables 3 and 5). For 1990-2000, the average temperature increased by about $0.39^{\circ} \mathrm{C}$ compared with $1975-1990$, while the average precipitation of the basin was about $181.27 \mathrm{~mm}$, an increase of about $29.43 \%$ more than the period 1975-1990, and all stations showed a significant increase in precipitation, and the rate of glacier retreat obviously slowed down (Table 5). In recent years from 2000 to 2016, the temperature of the basin had increased to $6.19^{\circ} \mathrm{C}$, an increase of $9.95 \%$ compared to the period of $1990-2000$, and glacier retreat since 2000 had accelerated compared to 1990-2000, but still lower than the period 1975-1990 because of the significant increase in precipitation. Under continue increasing temperatures, the glaciers of the basin are more sensitive to climate change, the retreat of glaciers existed in any period during 1975-2016, especially when the temperature increased more significant and the precipitation was little. Therefore, in the Aksu River Basin, although the quantitative relationship between glacier retreat and temperature rise is not very clear, the increase in precipitation partly compensates for the mass loss of glacier ice that resulted from increased temperatures affecting the glacier retreat rate in the Aksu River Basin. However, warming temperatures are clearly the main reason for glacier retreat in the region for the period 1975-2016.

\section{Discussion and conclusions}

The present study revealed the scientific value of detailed multitemporal remote sensing analyses of glacier changes in the Aksu River Basin where lacked sufficient records of observational data from 1975 to 2016. The study reached the following preliminary conclu- 
sions:

The vast majority of the glaciers in the Aksu River Basin were dominated by medium and small glaciers, there were 2011 small glaciers $\left(<1 \mathrm{~km}^{2}\right)$, about $74.26 \%$ of the total glacier number, which covered $21.49 \%$ of the total glacierized area. We have determined that glacial recession has occurred in the Aksu River Basin since 1975. We identified 2708 glaciers with a total area of $3731.24 \mathrm{~km}^{2}$ in 1975 that had decreased to 2506 by 2016 , a loss of $965.7 \mathrm{~km}^{2}$ (a shrinkage rate of $25.88 \%$, about $0.63 \% \mathrm{yr}^{-1}$ ). Moreover, the glacier areas of the east, southeast and south aspects decreased by $0.86 \% \mathrm{yr}^{-1}, 0.82 \% \mathrm{yr}^{-1}$ and $0.79 \% \mathrm{yr}^{-1}$, respectively, while the northwest aspect decreased by $18.48 \%$, only about $0.45 \% \mathrm{yr}^{-1}$. Compared with the adjacent glacierized basin, the glacier area of the basin showed a comparatively higher shrinkage rate, which is significantly higher than the Yarkant River Basin, a rate of $0.36 \%$ $\mathrm{yr}^{-1}$ (Feng et al., 2015), the Kaidu River Basin, $0.35 \% \mathrm{yr}^{-1}$ (Li et al., 2006) and the Tarim River Basin, about $0.08-0.11 \% \mathrm{yr}^{-1}$ (Shangguan et al., 2009). This may be due to the rapid temperature rise in the Aksu River Basin, especially in recent decades.

We have determined that the median elevation of the glaciers in the Aksu River Basin increased by $36.09 \mathrm{~m}$, while the elevation of the glacier termini rose by about $67.85 \mathrm{~m}$, from 4078.26 to $4146.11 \mathrm{~m}$ for $1975-2016$. The glacier median and average terminus elevation of the western Toxkan River Basin increased by $36.62 \mathrm{~m}$ and $67.42 \mathrm{~m}$, and the glacier median and average terminus elevation of the eastern Kumalak River Basin increased by $33.08 \mathrm{~m}$ and $63.69 \mathrm{~m}$.

The temperature of the basin increased by $1.56^{\circ} \mathrm{C}$, the rate was about $0.38^{\circ} \mathrm{C} 10 \mathrm{yr}^{-1}$ over the past 41 years. The increasing temperature not only accelerated the glacier retreat, but also reduced the rates of snowfall in mountain regions, and the decreased snowfall had a direct effect on glacier accumulation and ablation (Chen et al., 2017). It was mentioned that with the increase in temperature, the significantly increased precipitation compensated for the glacier mass loss to some extent. Meanwhile, the substantially increased precipitation may have some impacts on the rate of glacier retreat. A similar effect of precipitation on glacier retreat was observed elsewhere in the Tianshan Mountains and other mountain ranges (Bolch et al., 2010), as for example, the Terskey-Alatoo area in the inner Tianshan Mountains (Kutuzov and Shahgedanova, 2009), and in the Kaidu River Basin in the Central Tianshan Mountains (Li et al., 2006). Schauwecker (2014) and Vuille (2008) found that the glacier changes in the Cordillera Blanca region of Peru were mainly affected by precipitation change, and the significant increased precipitation made the glacier retreat rate and the elevation of glacier mass loss balance lines increased slower significantly in summer at high altitudes. Over the past 41 years, the glaciers in the Aksu River Basin had tended to shrink, but the rate of glacier retreat slowed down. By analysing the rate of glacier retreat of the two typical glaciers, the RGI50-13.09540 glacier of Toxkan River Basin and the RGI50-13.04920 glacier of Kumalak River Basin, the rate of the two typical glaciers retreat both slowed down obviously during 1990-2000 compared to 1975-1990. Furthermore, the rate of the RGI50-13.04920 glacier retreat had slowed down, from 1.02\% during 1975-1990 to $0.27 \%$ in the period $1990-2000$ and had decreased by about $0.15 \%$ in the period 2000-2016. Under the global warming and rising temperatures, the rate of glacier retreat may be directly related to the increasing of precipitation, except for the reasons of topography and altitude. 
A detailed study will continue to analyze the effects of future climate change in the extent and mass of the glaciers and snow on runoff, and, this study will help to improve integrated water resource management in the Aksu Basin and Tarim River.

\section{References}

Armstrong R L, 2010. The glaciers of the Hindu Kush-Himalayan region: A summary of the science regarding glacier melt/retreat in the Himalayan, Hindu Kush, Karakoram, Pamir, and Tien Shan mountain ranges. International Centre for Integrated Mountain Development, 1-16.

Barry R G, 2006. The status of research on glaciers and global glacier recession: A review. Phog. Phys. Geog., 30(3): 285-306.

Bolch T, 2007. Climate change and glacier retreat in northern Tien Shan (Kazakhstan/Kyrgyzstan) using remote sensing data. Global Planet. Change, 56(1): 1-12.

Bolch T, Yao T, Kang S et al., 2010. A glacier inventory for the western Nyainqentanglha Range and the Nam Co Basin, Tibet, and glacier changes 1976-2009. Cryosphere, 4(3): 419-433.

Chen Y N, Li W H, Deng H J et al., 2016. Changes in Central Asia's Water Tower: Past, Present and Future. Sci. Rep-UK, 6: 35458.

Chen Y N, Li W H, Fang G H et al., 2017. Impact of climate change on water resources in the Tianshan Mountains, Central Asia. Acta Geographica Sinica, 72(1): 18-26. (in Chinese)

Chen Y N, Li Z, Fan Y T et al., 2014. Research progress on the impact of climate change on water resources in the arid region of Northwest China. Acta Geographica Sinica, 69(9): 1295-1304. (in Chinese)

Deng H J, Chen Y N, 2017. Influences of recent climate change and human activities on water storage variations in Central Asia. J. Hydrol., 544: 46-57.

Ding Y H, Ren G Y, Zhao Z C et al., 2007. Detection, causes and projection of climate change over China: An overview of recent progress. Adv. Atmos. Sci., 24(6): 954-971.

Duethmann D, Bolch T, Farinotti D et al., 2015. Attribution of streamflow trends in snow and glacier melt-dominated catchments of the Tarim River, Central Asia. Water Resources Res., 51: 4727-4750.

Falorni G, Teles V, Vivoni E R et al., 2005. Analysis and characterization of the vertical accuracy of digital elevation models from the Shuttle Radar Topography Mission. J. Geophys. Res., 110(F2): 1-20.

Fan Y T, Chen Y N, Li W H, 2014. Increasing precipitation and baseflow in Aksu River since the 1950s. Quatern. Int., 336(12): 26-34.

Farinotti D, Longuevergne L, Moholdt G et al., 2015. Substantial glacier mass loss in the Tien Shan over the past 50 years. Nat. Geosci., 8(9): 716-722.

Feng T, Liu S Y, Xu J L et al., 2015. Glacier changes of the Yarkant River Basin from 1968 to 2009 derived from the First and Second Glacier Inventories of China. J. Glacio. Geocryology, 37(1): 1-13. (in Chinese)

Gardner A S, Moholdt G, Cogley J G et al., 2013. A reconciled estimate of glacier contributions to sea level rise: 2003 to 2009. Science, 340: 852-857.

Grinsted A, 2013. An estimate of global glacier volume. Cryosphere, 7(1): 141-151.

Haeberli W, Cihlar J, Barry R G, 2000. Glacier monitoring within the Global Climate Observing System. Ann. Glaciol., 31(1): 241-246.

Haeberli W, Hoelzle M, Paul F et al., 2007. Integrated monitoring of mountain glaciers as key indicators of global climate change: The European Alps. Ann. Glaciol., 46(1): 150-160.

Hagg W, Mayer C, Lambrecht A et al., 2013. Glacier changes in the Big Naryn basin, Central Tian Shan. Global Planet. Change, 110: 40-50.

Huai B J, Li Z Q, Sun M P et al., 2015. Change in glacier area and thickness in the Tomur Peak, western Chinese Tien Shan over the past four decades. J. Earth Syst. Sci., 124(2): 353-363.

IPCC, 2013. Climate Change 2013: The Physical Science Basis. Cambridge: Cambridge University Press, 1308.

Kaldybayev A, Chen Y N, Vilesov E, 2016. Glacier change in the Karatal River Basin, Zhetysu (Dzhungar) Alatau, Kazakhstan. Ann. Glaciol., 57(71): 11-19.

Krysanova V, Wortmann M, Bolch T et al., 2014. Analysis of current trends in climate parameters, river discharge and glaciers in the Aksu River basin (Central Asia). Hydrolog. Sci. J., 60(4): 566-590.

Kutuzov S and Shahgedanova M, 2009. Glacier retreat and climatic variability in the eastern Terskey-Alatoo, inner Tien Shan between the middle of the 19th century and beginning of the 21st century. Global Planet. Change, 69(1/2): 59-70.

Lai Z M, Cao Z T, Liu C H, 1986. Glacier catalogue of China III: Tianshan Mountain Area: The inner flow region of Zhungeer in Northwest China. Beijing: Science Press: 1-201. (in Chinese) 
Li B F, Chen Y N, Chen Z S et al., 2012. Trends in runoff versus climate change in typical rivers in the arid region of northwest China. Quatern. Int., 282: 87-95.

Li B L, Zhu A X, Zhang Y C et al., 2006. Glacier change over the past four decades in the middle Chinese Tien Shan. J. Glaciol., 52(178): 425-432.

Li X, Cheng G D, Jin H J et al., 2008. Cryospheric change in China. Global Planet. Change, 62(3/4): $210-218$.

Liu S Y, Ding Y J, Shangguan D H et al, 2006. Glacier retreat as a result of climate warming and increased precipitation in the Tarim River Basin, Northwest China. Ann. Glacio., 43(1): 91-96.

Machguth H, Huss M, 2014. The length of the world's glacier: A new approach for the global calculation of center lines. Cryosphere, 8(5): 1741-1755.

Nie Y, Zhang Y L, Liu L S et al., 2010. Monitoring glacier change based on remote sensing in the Mt. Qomolangma National Nature Preserve, 1976-2006. Acta Geographica Sinica, 65(1): 13-28. (in Chinese)

Nuth C, Moholdt G, Kohler J et al., 2010. Svalbard glacier elevation changes and contribution to sea level rise. $J$. Geophys. Re., 115(F1). https://agupubs.onlinelibrary.wiley.com/doi/abs/10.1029/2008JF001223.

Oerlemans J, 2005. Extracting a climate signal from 169 glacier records. Science, 308(5722): 675-677.

Ouyang R L, Cheng W M, Wang W S et al., 2007. Research on runoff forecast approaches to the Aksu River Basin. Science in China Series D, 50(1): 16-25.

Pan B T, Zhang G L, Wang J et al., 2012. Glacier changes from 1966-2009 in the Gongga Mountains, on the south-eastern margin of the Qinghai-Tibetan Plateau and their climatic forcing. Cryosphere, 6(5): 1087-1101.

Petrakov D, Shpuntova A, Aleinikov A et al., 2016. Accelerated glacier shrinkage in the Ak-Shyirak massif, Inner Tien Shan, during 2003-2013. Sci. Total Environ., 562: 364-378.

Pieczonka T, Bolch T, 2015. Region-wide glacier mass budgets and area changes for the Central Tien Shan between $\sim 1975$ and 1999 using Hexagon KH-9 imagery. Global Planet. Change, 128: 1-13.

Pieczonka T, Bolch T, Wei J F et al., 2013. Heterogeneous mass loss of glaciers in the Aksu-Tarim Catchment (Central Tien Shan) revealed by 1976 KH-9 Hexagon and 2009 SPOT-5 stereo imagery. Remote Sens. Environ., 130(4): 233-244.

Racoviteanu A, Williams M W, 2012. Decision tree and texture analysis for mapping debris-covered glaciers in the Kangchenjunga Area, Eastern Himalaya. Remote. Sens., 4(10): 3078-3109.

Radić V, Hock R, 2010. Regional and global volumes of glaciers derived from statistical upscaling of glacier inventory data. J. Geophys Res.-Earth, 115(F1).

Rodríguez E, Morris C S, Belz J E, 2006. A global assessment of the SRTM performance. Photogramm. Eng. Rem. Sens., 72(3): 249-260.

Schauwecker S, Rohrer M, Acuña D et al., 2014. Climate trends and glacier retreat in the Cordillera Blanca, Peru, revisited. Global Planet. Change, 119: 85-97.

Shangguan D H, Liu S Y, Ding Y J et al., 2009. Glacier changes during the last forty years in the Tarim interior river basin, Northwest China. Prog. Nat. Sci-Mater, 19(6): 727-732.

Shi Y F, 2008. Concise Glacier Inventory of China. Shanghai: Shanghai Popular Science Press, 205. (in chinese)

Sidjak R W, 1999. Glacier mapping of the Illecillewaet icefield, British Columbia, Canada, using Landsat TM and digital elevation data. Int. J. Remote Sens., 20(2): 273-284.

Sorg A, Bolch T, Stoffel M et al., 2012. Climate change impacts on glaciers and runoff in Tien Shan (Central Asia). Nat. Clim. Change, 2(10): 725-731.

Vuille M, Kaser G, Juen I, 2008. Glacier mass balance variability in the Cordillera Blanca, Peru and its relationship with climate and the large-scale circulation. Global Planet. Change, 62: 14-28.

Wang X, Liu S, Ding Y et al., 2012. An approach for estimating the breach probabilities of moraine-dammed lakes in the Chinese Himalayas using remote-sensing data. Nat. Hazard Hazard Earth Sys., 12(10): 3109-3122.

Wang P Y, Li Z Q, Xu C H et al., 2017. Multi-decadal variations in glacier flow velocity and the influencing factors of Urumqi Glacier No.1 in Tianshan Mountains, Northwest China. J. Arid Land, 9(6): 900-910.

Willmes S, Bareiss J, Haas C et al., 2009. Observing snowmelt dynamics on fast ice in Kongsfjorden, Svalbard, with NOAA/AVHRR data and field measurements. Polar Res., 28(2): 203-213.

$\mathrm{Xu} \mathrm{J}$ H, Chen Y N, Lu F et al., 2011. The Nonlinear trend of runoff and its response to climate change in the Aksu River, western China. Int. J. Climatol., 31(5): 687-695.

Yu X Y, Lu C H, 2015. Alpine Glacier Change in the Eastern Altun Mountains of Northwest China during 1972-2010. Plos One, 10(2): e0117262.

Zhao Q D, Zhang S Q, Ding Y J et al., 2015. Modeling hydrologic response to climate change and shrinking glaciers in the highly glacierized Kunma Like River Catchment, Central Tian Shan. J. Hydrometeorol., 16(6): 2383-2402. 